\title{
Spatial distribution of archaeal and bacterial ammonia oxidizers in the littoral buffer zone of a nitrogen-rich lake
}

\author{
Yu Wang ${ }^{1,2}$, Guibing Zhu ${ }^{1, *}$, Lei Ye $^{1,2}$, Xiaojuan Feng ${ }^{1}$, \\ Huub J. M. Op den Camp ${ }^{3}$, Chengqing Yin ${ }^{1}$ \\ 1. State Key Laboratory of Environmental Aquatic Quality, Research Center for Eco-Environmental Sciences, the Chinese Academy of Sciences, \\ Beijing 100085, China. E-mail: yuwang_st@rcees.ac.cn \\ 2. Graduate University of Chinese Academy of Sciences, Beijing 100039, China \\ 3. Department of Microbiology, IWWR, Radboud University Nijmegen, Nijmegen, 6525AJ, the Netherlands
}

Received 17 July 2011; revised 23 September 2011; accepted 27 September 2011

\begin{abstract}
The spatial distribution and diversity of archaeal and bacterial ammonia oxidizers (AOA and AOB) were evaluated targeting amoA genes in the gradient of a littoral buffer zone which has been identified as a hot spot for $\mathrm{N}$ cycling. Here we found high spatial heterogeneity in the nitrification rate and abundance of ammonia oxidizers in the five sampling sites. The bacterial amoA gene was numerically dominant in most of the surface soil but decreased dramatically in deep layers. Higher nitrification potentials were detected in two sites near the land/water interface at 4.4-6.1 $\mu \mathrm{g} \mathrm{NO}_{2}{ }^{-}-\mathrm{N} /(\mathrm{g}$ dry weight soil. $\mathrm{hr})$, while only $1.0-1.7 \mu \mathrm{g} \mathrm{NO}{ }^{-}-\mathrm{N} /(\mathrm{g}$ dry weight soil.hr) was measured at other sites. The potential nitrification rates were proportional to the amoA gene abundance for AOB, but with no significant correlation with AOA. The $\mathrm{NH}_{4}{ }^{+}$concentration was the most determinative parameter for the abundance of $\mathrm{AOB}$ and potential nitrification rates in this study. Higher richness in the surface layer was found in the analysis of biodiversity. Phylogenetic analysis revealed that most of the bacterial amoA sequences in surface soil were affiliated with the genus of Nitrosopira while the archaeal sequences were almost equally affiliated with Candidatus 'Nitrososphaera gargensis' and Candidatus 'Nitrosocaldus yellowstonii'. The spatial distribution of AOA and $\mathrm{AOB}$ indicated that bacteria may play a more important role in nitrification in the littoral buffer zone of a N-rich lake.
\end{abstract}

Key words: littoral zone; ammonia oxidation; archaea; bacteria; heterogeneity; abundance

DOI: $10.1016 / \mathrm{S} 1001-0742(11) 60861-9$

\section{Introduction}

Littoral buffer zones, which are located at the transition between terrestrial and aquatic ecosystems, are considered as biogeochemical hot spots (McClain et al., 2003). Enhanced fluxes of nitrogen $(\mathrm{N})$ in littoral buffer zones, such as disproportionately high nitrous oxide $\left(\mathrm{N}_{2} \mathrm{O}\right)$ emission coupled with nitrate $\left(\mathrm{NO}_{3}{ }^{-}\right)$removal, has been recognized for decades (Verhoeven et al., 2006; Wang et al., 2006; Van den Heuvel et al., 2009; Vidon et al., 2010). The rate of $\mathrm{N}$ transformation in littoral buffer zones is affected by many factors, including soil moisture, temperature and carbon availability (Tiedje, 1988). However, the availability of $\mathrm{NO}_{3}{ }^{-}$, which is driven by microbial nitrification, is always the most important one (Groffman and Tiedje, 1989; Morris, 1991; Merrill and Zak, 1992).

Nitrification is the microbial oxidation of ammonia, first to nitrite and subsequently to nitrate. It is a key process in the $\mathrm{N}$ cycle and until recently was attributed to the Bacteria encoding $\alpha$ subunit of ammonia monooxyge-

\footnotetext{
* Corresponding author. E-mail: gbzhu@ @rcees.ac.cn
}

nase $($ amoA), specifically members of $\beta$-Proteobacteria and $\gamma$-Proteobacteria (Peng and Zhu 2006; Zhu et al., 2008). However, previous metagenomic studies revealed that some Crenarchaeota within the domain Archaea also express genes related to bacterial amoA (Könneke et al., 2005; Treusch et al., 2005). Subsequently, they were detected and shown to be widespread in nature, e.g. in soil (Leininger et al., 2006), marine environments (Wuchter et al., 2006), bioreactors (Park et al., 2006), and hot springs (Hatzenpichler et al., 2008).

The compositions and relative abundance of ammonia oxidizing archaea (AOA) and ammonia oxidizing bacteria (AOB) vary widely in many environments (Leininger et al., 2006; Wuchter et al., 2006; Di et al., 2009; Höfferle et al., 2010; Wang et al., 2011), but a consensus is that AOA may be important actors in the $\mathrm{N}$ cycle under unfavorable environmental conditions, e.g., limited nutrient availability, extreme $\mathrm{pH} /$ salinity or sulfide-containing environments (Erguder et al., 2009). However, the contribution to nitrification of $\mathrm{AOA}$ versus $\mathrm{AOB}$ remains less certain. Divergent conclusions have been drawn in territorial and aquatic ecosystems (Wuchter et al., 2006; Di et al., 2009; 
Jia and Conrad, 2009).

The littoral buffer zone harbors a changing environment between land and water, which suggests a complex microbial nitrification (Zhu et al., 2010, 2011). However, knowledge about the ammonia oxidizing communities in the littoral buffer zone remains unclear, but is essential for us to understand the $\mathrm{N}$ cycle. In the present study, we attempted to elaborate on the spatial distribution and roles of AOA and AOB in a N-rich littoral buffer zone. Quantitative PCR combined with clone library approaches based on amoA genes were used to characterize the abundance and community compositions of AOA and AOB.

\section{Materials and methods}

\subsection{Site description and sample collection}

The field experimental site was located at the Baiyangdian Lake $\left(38^{\circ} 54^{\prime} 16.8^{\prime \prime} \mathrm{N}, 115^{\circ} 55^{\prime} 26.3^{\prime \prime} \mathrm{E}\right)$, the largest freshwater body in North China. Baiyangdian Lake is a N-rich (in the form of $\mathrm{NH}_{4}{ }^{+}-\mathrm{N}$ ) lake. The contents of $\mathrm{NH}_{4}{ }^{+}-\mathrm{N}$, $\mathrm{NO}_{2}{ }^{-}-\mathrm{N}, \mathrm{NO}_{3}{ }^{-}-\mathrm{N}$, total nitrogen $(\mathrm{TN})$, and total organic carbon (TOC) in the lake water of the sampling site were $1.43,0.03,0.01,1.64$ and $0.67 \mathrm{mmol} / \mathrm{L}$, respectively. The water depth was $1.7 \mathrm{~m}$ with dissolved oxygen in the surface and deep water of 2.7 and $1.3 \mathrm{mg} / \mathrm{L}$ respectively. A local reed (Phragmites australis var. Baiyangdiansis) is the dominant hydrophyte.

Samples were collected in a land to water gradient area at a littoral buffer zone. Five samples were taken in September of 2009 as shown in Fig. 1. Samples on land (sites C, D and E) were collected at distances of 0.5, 2 and $5 \mathrm{~m}$ from the land/water interface and sliced every $10 \mathrm{~cm}$ with depths of 40,80 and $80 \mathrm{~cm}$, respectively. Samples in the water area (site A and B) were collected at distances of 1.5 and $6 \mathrm{~m}$ from the land/water interface. Samples in site A were collected as a surface sample $(0-10 \mathrm{~cm})$ while at a depth of $40 \mathrm{~cm}$ at site B.

\subsection{Soil chemical analysis}

$\mathrm{NH}_{4}{ }^{+}-\mathrm{N}$ and $\mathrm{NO} x^{-}-\mathrm{N}$ were determined by a Continuous Flow Analyzer $\left(\mathrm{SAN}^{++}\right.$, Skalar Analytical, the Netherlands) with extracted samples $(2 \mathrm{~mol} / \mathrm{L} \mathrm{KCl}$ as the extraction buffer). $\mathrm{Fe}^{2+}$ was measured from extracted solutions with Ferrozine reagent and the total iron $\left(\mathrm{Fe}^{2+}\right.$ plus $\mathrm{Fe}^{3+}$ ) was determined using reducing Ferrozine (Ferrozine reagent with $1 \%$ hydroxylamine-hydrochloride) by reading the absorbance at $562 \mathrm{~nm}$ after a minimum of three hours (Canfield et al., 1993). Briefly, a $0.3 \mathrm{~g}$ fresh sample was extracted with $5 \mathrm{~mL}$ oxalate $(0.2 \mathrm{~mol} / \mathrm{L}$ ammonium oxalate/oxalic acid, at pH 3 (Phillips and Lovley, 1987)) for 6 hr. The oxalate extraction was shaken at room temperature anaerobically, in the dark (Canfield et al.,1993).

The potential nitrification rate (PNR) was measured according to the chlorate inhibition method (Kurola et al., 2005). Briefly, $5.0 \mathrm{~g}$ of fresh sample was added into a 50$\mathrm{mL}$ centrifuge tube containing $20 \mathrm{~mL}$ phosphate buffer solution (in $\mathrm{g} / \mathrm{L}, \mathrm{NaCl}, 8.0 ; \mathrm{KCl}, 0.2 ; \mathrm{Na}_{2} \mathrm{HPO}_{4}, 0.2$; $\mathrm{NaH}_{2} \mathrm{PO}_{4}, 0.2$; and $\left.\mathrm{pH} 7.4\right)$ with $1 \mathrm{mmol} / \mathrm{L}\left(\mathrm{NH}_{4}\right)_{2} \mathrm{SO}_{4}$. Potassium chlorate with a final concentration of 10 $\mathrm{mmol} / \mathrm{L}$ was added to inhibit the nitrite oxidation. The suspension was incubated in the dark at $25^{\circ} \mathrm{C}$ for $24 \mathrm{hr}$, and nitrite was extracted with $5 \mathrm{~mL}$ of $2 \mathrm{~mol} / \mathrm{L} \mathrm{KCl}$ and determined by a spectrophotometer at a wavelength of 540 nm with N-(1-naphthyl) ethylenediamine dihydrochloride. Apparent potential nitrification rates were calculated from the linear increase in concentrations of $\mathrm{NO}_{2}{ }^{-}$during the first $12 \mathrm{hr}$. The actual nitrification rates might be slightly higher owing to the possibility of denitrification, so the loss of $\mathrm{NO}_{2}{ }^{-}$cannot be fully excluded even in oxic incubations.

\subsection{DNA extraction}

DNA was extracted using a MoBio UltraClean soil DNA Isolation Kit (MoBio, Carlsbad, USA) from a $0.25 \mathrm{~g}$ fresh sample. DNA was eluted with $50 \mu \mathrm{L}$ of solution S5 (MoBio Laboratories, cat. No. 12800-100). Water DNA was extracted with the PowerWater DNA Isolation Kit with $0.22 \mu \mathrm{m}$ filter (MoBio, Carlsbad, USA) from $800 \mathrm{~mL}$ water according to manufacturer instructions. Water DNA was

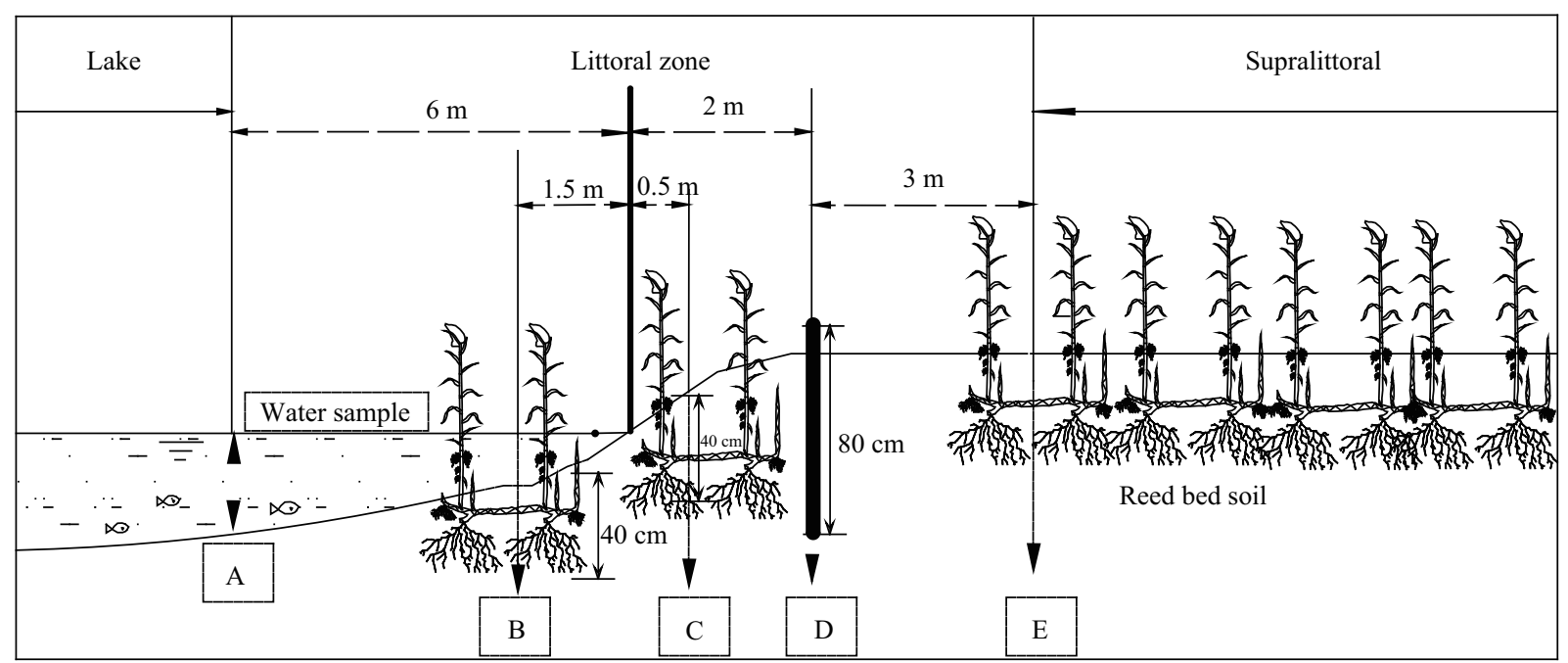

Fig. 1 Diagrammatic sketch of the sampling sites in a littoral buffer zone. Five samples were taken in the water area (sites A and B) and on land (sites C, D and E). 
eluted with $50 \mu \mathrm{L}$ PW6 solution (MoBio Laboratories, cat. No. 14900-100). DNA was stored at $-20^{\circ} \mathrm{C}$ before use.

\subsection{PCR, cloning and sequence analysis}

Primer pairs amoA1F (GGGGTTTCTACTGGTGGT)/amoA2R (CCCCTCKGSAAAGCCTTCTTC) (Rotthauwe et al., 1997) and Arch-amoAF (STAATGGTCTGGCTTAGACG)/Arch-amoAR (GCGGCCATCCATCTGTATGT) (Francis et al., 2005) were used for the amplification of bacterial and archaeal amoA genes, respectively. PCR reactions $(50 \mu \mathrm{L})$ contained $5 \mu \mathrm{L} 10 \times$ PCR buffer $\left(\mathrm{Mg}^{2+}\right.$ plus $), 4 \mu \mathrm{L}$ dNTPs $(2.5 \mathrm{mmol} / \mathrm{L}), 0.5 \mu \mathrm{L}$ Ex Taq polymerase (5 $\mathrm{U} / \mu \mathrm{L}, \mathrm{TAKARA}$, Dalian, China), $1 \mu \mathrm{L}$ of each primer $(20$ $\mathrm{mmol} / \mathrm{l})$, and $2 \mu \mathrm{L}$ DNA template (1-10 ng).

The PCR product was gel-purified and ligated into the pGEM-T Easy Vector (Promega, Madison, USA). The resulting ligation products were used to transform Escherichia coli JM109 competent cells following the instructions of the manufacturer. PCR screened directly for the presence of inserts by the use of T7 and SP6 vector primers, and the amplicons were analyzed with restriction endonuclease HhaI (TAKARA, Dalian, China). Restriction digestion was carried out in a total volume of $20 \mu \mathrm{L}$ including $5 \mathrm{U}$ of restriction enzymes and $4 \mu \mathrm{L}$ of PCR products, and the system was incubated for $2 \mathrm{hr}$ at $37^{\circ} \mathrm{C}$. Digested DNA fragments were analyzed by separation of fragments on a $2 \%(W / V)$ agarose gel and visualized with a GBOX/HR-E-M (Syngene, UK). Representative clones from each digestion pattern were selected for sequencing using an ABI 3730XL (Applied Biosystems, USA) automated sequencer. Positive clones were selected to isolate plasmid DNA using a GeneJet Plasmid Miniprep Kit (Fermentas MBI, Lithuania) as amoA gene standards. The plasmid DNA concentration was determined on a Nanodrops ND-1000 UV-Vis Spectrophotometer (NanoDrop Technologies, USA) for calculation of amoA gene copy number. Phylogenetic analysis based on nucleotide sequences was performed using MEGA version 4.0 (Tamura et al., 2007) and a neighbor-joining tree was constructed using Kimura two-parameter distance with 1000 replicates to produce bootstrap values. The archaeal and bacterial amoA gene sequences obtained in this study are available in the GenBank nucleotide sequence database under the accession Nos. HQ202364-HQ202535.

\subsection{Quantitative PCR}

The same primer pairs were subjected to quantitative PCR assay as described above. Amplification and detection were carried out with an ABI Prism 7300 Sequence Detection System (Applied Biosystems, USA) as follows: $50^{\circ} \mathrm{C}$ for $2 \mathrm{~min}, 95^{\circ} \mathrm{C}$ for $30 \mathrm{sec}$, followed by 40 cycles of $10 \mathrm{sec}$ at $95^{\circ} \mathrm{C}, 30 \mathrm{sec}$ at $53^{\circ} \mathrm{C}$ for $\mathrm{AOA}$ or $55^{\circ} \mathrm{C}$ for $\mathrm{AOB}$, and $1 \mathrm{~min}$ at $72^{\circ} \mathrm{C}$. The $25 \mu \mathrm{L}$ reaction volume contained 12.5 $\mu \mathrm{L}$ SYBRs Premix Ex Taq (TAKARA, Dalian, China), $1 \mu \mathrm{L}$ of AOA or AOB primer sets (20 $\mathrm{mmol} / \mathrm{L}$ ) and $2 \mu \mathrm{L}$ of 10 -fold diluted DNA as a template. Three replicates were analyzed for each sample. Tenfold serial dilutions with known copy numbers of the plasmid
DNA were subjected to quantitative PCR in triplicate to generate an external standard curve.

\subsection{Statistical analysis}

To obtain information on the richness and diversity of archaeal and bacterial amoA genes, operational taxonomic units (OTUs) for community analysis were defined by $3 \%$ differences in nucleotide sequences, as determined by using the furthest neighbor algorithm in DOTUR (Schloss and Handelsman, 2005). Shannon and Simpson indices for each clone library were also generated by DOTUR. The statistical analyses were conducted by Pearson correlation analysis with the program of Statistical Product and Service Solutions (SPSS). Graphing was achieved using Origin 7.5 software.

\section{Results}

\subsection{Spatial distribution of AOA, AOB and potential nitrification rate in surface samples}

The abundance of AOA and AOB were investigated by quantitative PCR targeting their amoA genes. A relatively higher abundance of AOB was detected in the sites near the land/water interface. The highest AOB abundance was observed in site $\mathrm{B}$ at $2.1 \times 10^{9}$ copies/g dry weight soil (dws). Samples at site $\mathrm{C}$ also showed a high abundance at $1.2 \times 10^{8}$ copies/g dws. In the sites D and $\mathrm{E}$ which were relatively far from the interface, the abundance of $\mathrm{AOB}$ was much lower at $7.6 \times 10^{6}$ and $6.7 \times 10^{5}$ copies/g dws, respectively. The AOA showed minor variations ranging from $4.8 \times 10^{6}$ to $1.7 \times 10^{8}$ copies/g dws, but the average was much higher on land than that in the water area. In sites $\mathrm{D}$ and $\mathrm{E}$, the ammonium oxidizer communities were dominated by $\mathrm{AOA}$ with the ratio of $\mathrm{AOA} / \mathrm{AOB}$ at 2.59 and 246, respectively. On the contrary, the AOB were more dominant in sites $\mathrm{A}$ and $\mathrm{B}$ and the transition site $\mathrm{C}$ with $\mathrm{AOA} / \mathrm{AOB}$ ratios of $0.46,0.002$ and 0.274 , respectively.

To investigate the nitrification activity along the littoral buffer zone, the potential nitrification rate (PNR) was measured. The results showed that PNRs varied a lot and showed a high heterogeneity in the surface samples (Fig. 2). High PNRs were observed in the sites B and C which were close to the land/water interface. The highest PNR showed up in the site $\mathrm{B}$ at $6.2 \mu \mathrm{g} \mathrm{NO}_{2}{ }^{-} \mathrm{-N} /(\mathrm{g}$ dws $\cdot h r)$. By comparison, in the sites on land (sites D and $\mathrm{E}$ ), the PNR were 6 times lower than that of site B at 0.9 and $1.0 \mu \mathrm{g}$ $\mathrm{NO}_{2}{ }^{-}-\mathrm{N} /(\mathrm{g}$ dws $\cdot h r)$, respectively. These results indicated that the area of $0.5-2 \mathrm{~m}$ around the land/water interface was a hot zone of nitrification in the littoral buffer zone. In general, the abundance of AOB varied greatly along the littoral buffer zone and was consistent with the variation of PNR. However, the AOA abundance was relative steady and little heterogeneity was observed.

\subsection{Vertical distribution of AOA, AOB and PNR}

The variety and heterogeneity of AOA, AOB and PNR in surface samples prompted our investigation into their vertical distributions. Sites B, C and D, which were close 


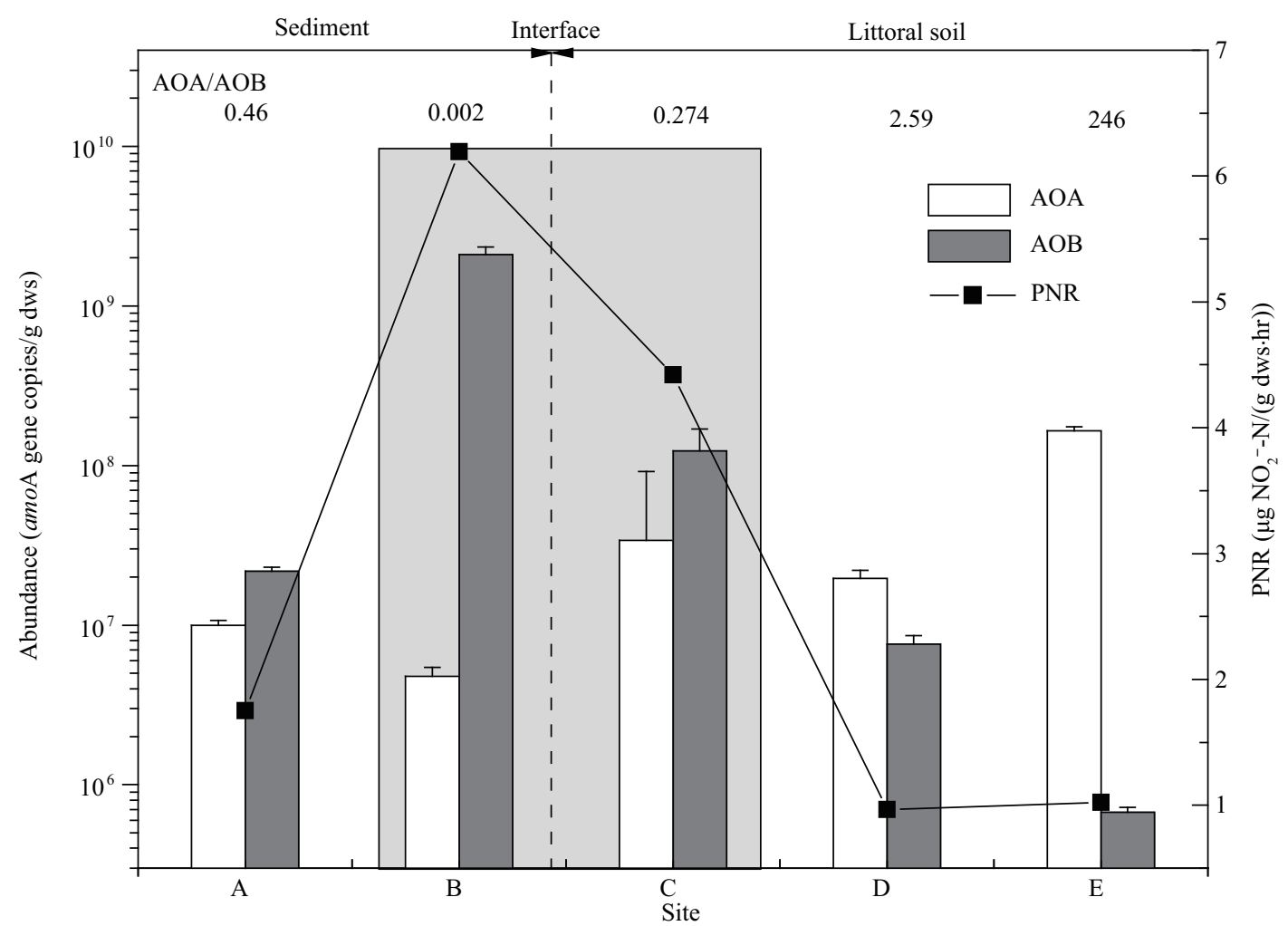

Fig. 2 Potential nitrification rates (PNR) in surface samples of the littoral buffer zone and the relevant archaeal and bacterial amoA gene copy numbers. Error bars indicate standard deviation $(n=3)$. Sites with higher PNRs are labeled with grey background.

to the land/water interface and showed higher PNRs in surface samples, were studied to investigate the vertical profiles. Samples in sites B and C were taken from 0-40 $\mathrm{cm}$ representing the littoral soil. The soil core in site D was taken down to a depth of $80 \mathrm{~cm}$ to cover most of the biogeochemically active layers in soil, according to previous studies (Jia and Conrad, 2009; Höfferle et al., 2010). Still, heterogeneity was observed for the abundance of AOB and PNR in the vertical distributions.

In the sites $\mathrm{B}$ and $\mathrm{C}$ near the interface, although high abundance of the bacterial amoA gene was observed in surface samples, it decreased dramatically in deep samples as shown in Fig. 3. Especially at site B, the abundance of the bacterial amoA gene decreased from $2.1 \times 10^{9}$ in the surface layer to $4.9 \times 10^{7}$ at $10-20 \mathrm{~cm}$. On the contrary, the abundance of the archaeal amoA gene remained relatively invariant. Subsequently, the AOB $\left(4.9 \times 10^{5}\right.$ copies/g dws $)$ were no longer dominant over AOA $\left(6.2 \times 10^{6}\right.$ copies/g dws) below $20-30 \mathrm{~cm}$ depth. A similar variety in site $C$ was observed and samples in all deep soils were dominated by AOA due to the lower abundance of AOB. The decrease of PNRs in deep soil was observed again between two tested layers (0-10 and 30-40 cm) in sites B and C, which was consistent with the variation of AOB. In the soil core of site $\mathrm{D}$, which was relatively far from the interface, the abundance of AOB decreased along the depth as in sites B and $\mathrm{C}$ and could only be detected from 0 to $50 \mathrm{~cm}$ depth. However, the abundance of archaeal amoA gene was still as high as $7.0 \times 10^{6}$ copies/g dws in the layer at $70-80$ $\mathrm{cm}$. Similar to the PNRs in surface samples, the vertical distribution of PNRs correlated well with the abundance of AOB.

\subsection{Richness and phylogeny of AOA and AOB}

To analyze the richness and phylogeny of AOA and AOB, water samples, surface soil from site B and soil samples from cores (sites C, D and E), which were divided into surface and bottom layers (40 or $80 \mathrm{~cm}$ ), were amplified targeting the amoA genes. 105 archaeal and 91 bacterial amoA clones were sequenced and grouped into 40 and 34 operational taxonomic units (OTUs) for AOA and AOB, respectively (Table 1). The highest AOA richness occurred

Table 1 Diversity characteristics of each clone library of archaeal and bacterial amoA genes in different sample position

\begin{tabular}{llllll}
\hline $\begin{array}{l}\text { amoA } \\
\text { gene }\end{array}$ & $\begin{array}{l}\text { Sampling } \\
\text { position }\end{array}$ & $\begin{array}{l}\text { Number of } \\
\text { screened } \\
\text { clones }\end{array}$ & $\begin{array}{l}\text { OTU } \\
\text { number }\end{array}$ & $\begin{array}{l}\text { Shannon } \\
\text { index }\end{array}$ & $\begin{array}{l}\text { Simpson } \\
\text { index }\end{array}$ \\
\hline AOA & Water & 12 & 5 & 1.33 & 0.27 \\
& B (surface) & 14 & 1 & 0.39 & 0.75 \\
& C (surface) & 12 & 5 & 1.29 & 0.29 \\
& C (bottom) & 13 & 3 & 0.63 & 0.64 \\
& D (surface) & 15 & 10 & 2.21 & 0.06 \\
& D (bottom) & 13 & 9 & 2.04 & 0.09 \\
& E (surface) & 12 & 3 & 1.06 & 0.31 \\
& E (bottom) & 14 & 4 & 1.25 & 0.25 \\
& Water & 13 & 6 & 1.73 & 0.12 \\
& B (surface) & 15 & 6 & 1.45 & 0.24 \\
& C (surface) & 14 & 4 & 1.23 & 0.29 \\
& C (bottom) & ND & ND $^{\mathrm{a}}$ & $\mathrm{ND}^{\mathrm{a}}$ & $\mathrm{ND}^{\mathrm{a}}$ \\
& D (surface) & 14 & 6 & 1.66 & 0.15 \\
& D (bottom) & 12 & 1 & $\mathrm{ND}^{\mathrm{b}}$ & $\mathrm{ND}^{\mathrm{b}}$ \\
& E (surface) & 12 & 5 & 1.41 & 0.22 \\
& E (bottom) & 11 & 6 & 1.48 & 0.23 \\
\hline
\end{tabular}

$\overline{{ }^{a} \text { AOB were not detected with PCR; }{ }^{\mathrm{b}} \text { indices were absent at } 0.03 \text { level }}$ difference.

OTU: operational taxonomic unit. 

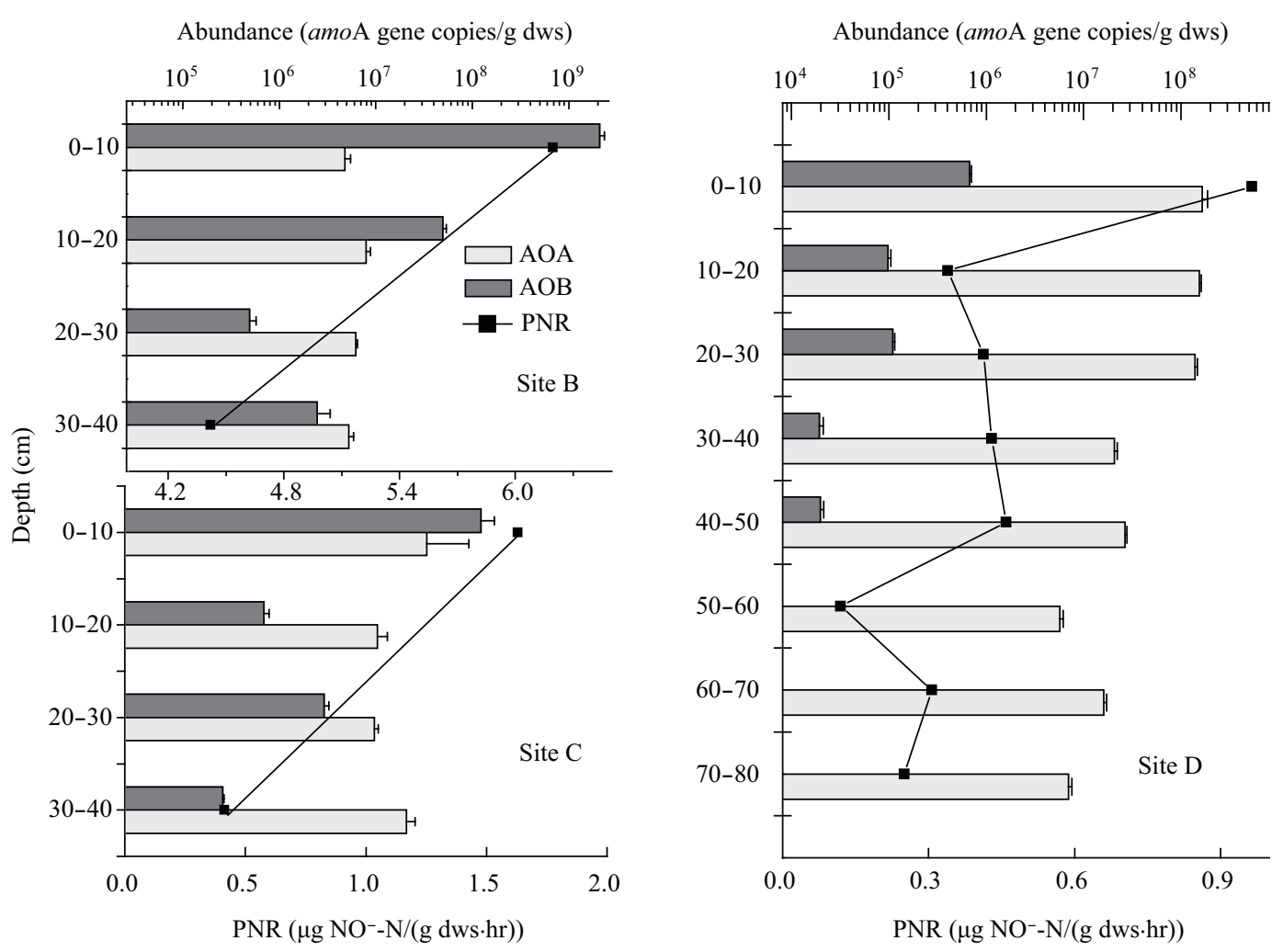

Fig. 3 Comparison of vertical profiles of amoA gene abundance and PNR in the sites near the land/water interface (sites B, C and D). Error bars indicate standard deviation $(n=3)$.

at site $\mathrm{D}$ both in the surface and bottom layers. The lowest value occurred in site $B$ in which only one OTU was defined, which was in agreement with the results of the Shannon and Simpson indices. The highest AOB richness occurred in the water sample, and the surface soil in site D still showed a higher richness among all the soil samples evaluated. In addition, AOA showed a higher richness than $\mathrm{AOB}$, and the surface layer showed a relative higher richness compared with the bottom layer either for AOA or AOB judging from the richness indices and OTU numbers.

Phylogenetic analysis showed that 40 archaeal amoA OTUs were divided into two branches (Fig. 4). One branch fell into a phylogenetic group comprising 21 OTUs and some published sequences recovered from soils in various ecosystems. Most of the OTUs in this branch were closely related to the putative AOA sequence of Candidatus 'Nitrososphaera gargensis' (EU281319). The other branch consisted of 19 OTUs and was divided into two groups. The first group clearly related to some amoA sequences from soil or sediment, whereas the second one only consisted of 4 OTUs from bottom layer soil and affiliated with $a m o \mathrm{~A}$ sequences from water or sediment. Moreover, they were closely related to the putative AOA sequence of Candidatus 'Nitrosocaldus yellowstonii' (EU239961).

The 34 bacterial amoA OTUs were divided into three groups (Fig. 5). One of the groups consisted of 18 OTUs and some published Nitrosospira-like amoA sequences. The exceptions in this group were the four OTUs closely related to Nitrosolobus multiformis (X90822) which has shown a close phylogenic relationship with Nitrosospira (Koops and Pommerening Röser, 2001). Most of the OTUs from the surface layer (12 out of 15 OTUs) were observed in this group. The second group consisted of 7 OTUs which were mostly retrieved from sediment and water samples (6 OTUs) and closely related to Nitrosomonas oligotropha (AF272406). Another Nitrosomonas group consisted of 9 OTUs and was closely related to Nitrosomonas nitrosa (AJ238495).

\subsection{Correlations of ammonia-oxidizer community structures with environmental factors}

Pearson's moment correlation analysis was performed to find out whether there were environmental factors affecting the distributions of AOA and AOB (Table 2). Results showed that the PNRs were significantly correlated with the abundance of $\mathrm{AOB}$, and the $\mathrm{AOB}$ abundance was correlated well with $\mathrm{NH}_{4}{ }^{+}-\mathrm{N}$. Meanwhile, no significant correlation was observed between the abundance of AOA and environmental factors. In addition, a significantly negative correlation was found between the Simpson index of AOA and $\mathrm{NH}_{4}{ }^{+}$which indicated that the high concentration of $\mathrm{NH}_{4}^{+}$may depress the biodiversity of AOA in the littoral buffer zone.

\subsection{Cell-specific ammonia oxidation rates}

Cell-specific ammonia oxidation rates in the littoral buffer zone were inferred from the observed PNRs and the amoA gene copy numbers (Table 3). For AOB, cellspecific rates of ammonia oxidation in surface samples ranged from 0.02 to $10.90 \mathrm{fmol} \mathrm{NH}_{3}$ oxidized/(cell.hr), mostly within those reported in the literature (Belser, 1979; Ward et al., 1989; Wagner et al., 1995; Okano et al., 2004; Könneke et al., 2005; Treusch et al., 2005; Jia and Conrad, 2009). One exception was the low cell-specific 


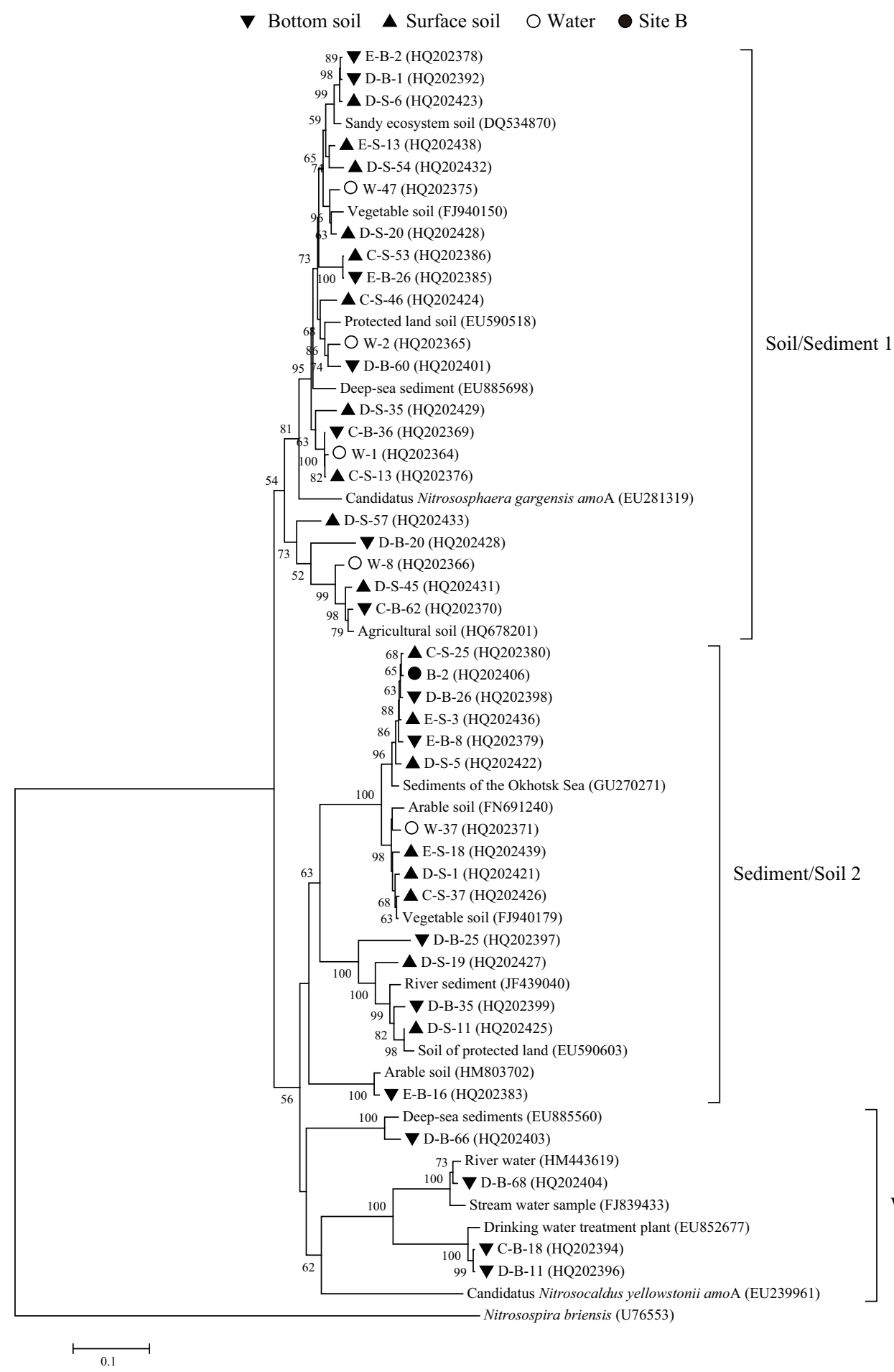

Water/Sediment

Fig. 4 Phylogenetic tree of archaeal amoA genes from water, site B and surface and bottom soil of C, D, E sites. Bootstrap values (>50\%) are indicated at branch points. Branch lengths correspond to sequence differences as indicated by the scale bar. Nitrosospira Briensis (U76553) was used as outgroup. The accession number of each sequence in this study is indicated in parentheses.

rates of $\mathrm{AOB}$ in the surface sample of site $\mathrm{B}$ indicating that the detected AOB community was not likely to be fully actively involved in nitrification. For AOA, on the other hand, some extraordinarily high cell-specific rates (0.93-9.28 versus $0.08-0.59 \mathrm{fmol} \mathrm{NH}_{3}$ oxidized/(cell.hr) in pure culture), especially in site $\mathrm{A}$ and $\mathrm{B}$, were observed, suggesting that the AOA community could not account for the nitrification solely and that $\mathrm{AOB}$ were indispensable in ammonia oxidation. Note that the cell-specific rates did not reflect the actual activity because the rates were inferred assuming solely AOA or AOB was functionally involved in ammonia oxidation. Moreover, the rates of AOA are roughly estimated, because presently only two reports allowed calculation of such rates.

\section{Discussion}

The littoral buffer zones as the hot spots of $\mathrm{N}$ cycling has been well recognized for decades (Wang et al., 2006; Vidon et al., 2010). However, nitrification as the rate 
Bottom soil $\Delta$ Surface soil O Water $\bullet$ Site B

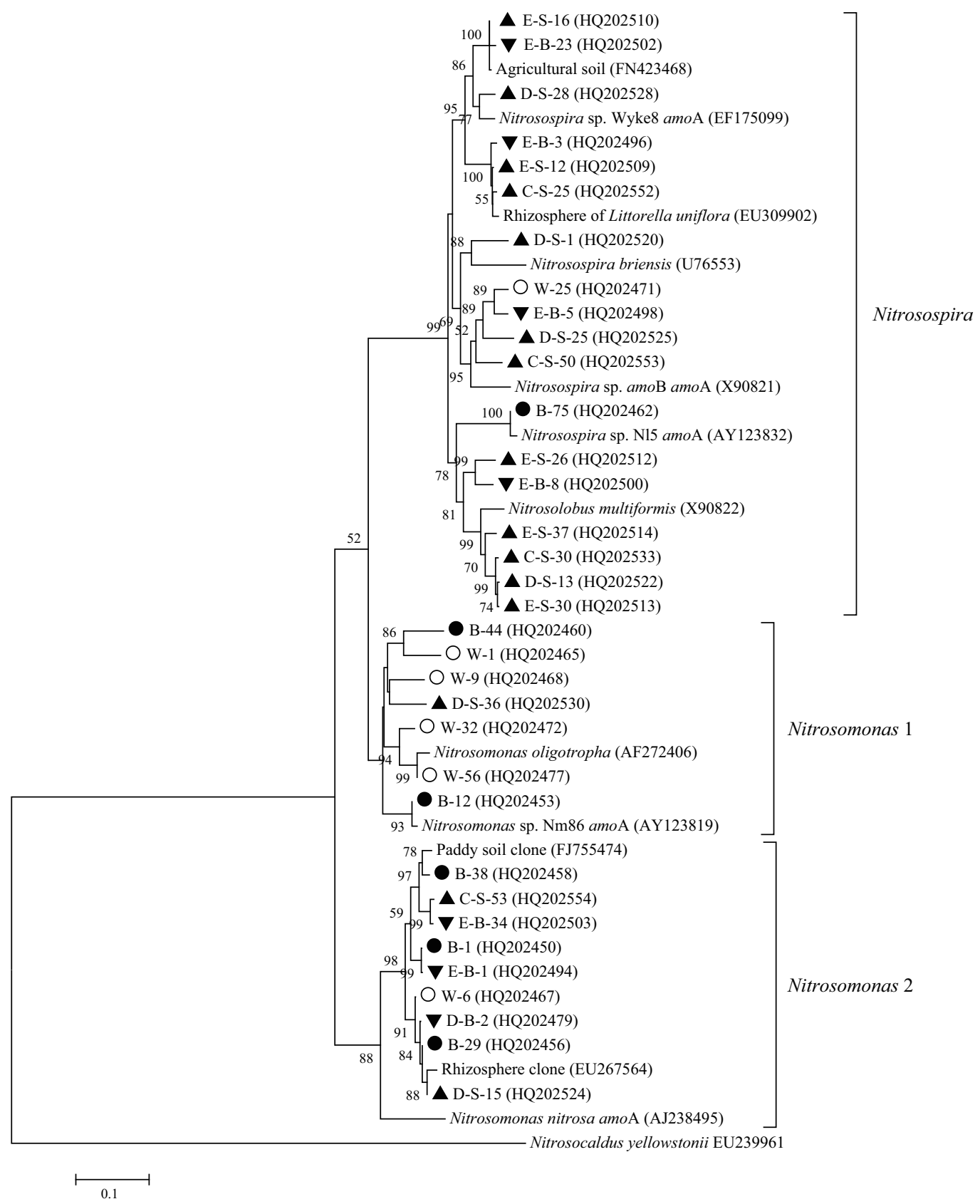

Fig. 5 Phylogenetic tree of archaeal amoA genes from water, site B and surface and bottom soil of C D E sites. Bootstrap values (> 50\%) are indicated at branch points. Branch lengths correspond to sequence differences as indicated by the scale bar. Nitrosocaldus yellowstonii (EU239961) was used as outgroup. The accession number of each sequence in this study is indicated in parentheses.

Table 2 Correlation coefficients between chemical properties and community structures of AOA and AOB

\begin{tabular}{|c|c|c|c|c|c|c|c|c|c|c|}
\hline & \multirow[t]{2}{*}{ PNR } & \multicolumn{3}{|c|}{ Abundance } & \multicolumn{2}{|c|}{ OTU number } & \multicolumn{2}{|c|}{ Shannon index } & \multicolumn{2}{|c|}{ Simpson index } \\
\hline & & $\mathrm{AOA}$ & AOB & $\mathrm{AOA} / \mathrm{AOB}$ & $\mathrm{AOA}$ & $\mathrm{AOB}$ & $\mathrm{AOA}$ & $\mathrm{AOB}$ & $\mathrm{AOA}$ & $\mathrm{AOB}$ \\
\hline PNR & - & 0.069 & $0.821^{\mathrm{a}}$ & -0.059 & -0.719 & 0.439 & -0.793 & 0.391 & 0.863 & $\overline{0.707}$ \\
\hline $\mathrm{NH}_{4}{ }^{-}-\mathrm{N}$ & $0.871^{\mathrm{a}}$ & -0.136 & $0.475^{b}$ & -0.159 & -0.608 & 0.307 & -0.686 & 0.202 & $0.809^{a}$ & 0.330 \\
\hline $\mathrm{NO} x^{-}-\mathrm{N}$ & -0.144 & 0.418 & -0.021 & 0.461 & -0.467 & 0.411 & -0.295 & 0.366 & 0.036 & 0.341 \\
\hline TOC & 0.209 & 0.301 & 0.294 & 0.269 & -0.381 & 0.064 & -0.315 & 0.032 & 0.282 & 0.048 \\
\hline $\mathrm{pH}$ & -0.288 & -0.211 & -0.152 & -0.140 & 0.546 & 0.251 & 0.560 & 0.149 & -0.513 & -0.343 \\
\hline $\mathrm{Fe}^{2+}$ & 0.090 & -0.251 & 0.206 & -0.241 & -0.336 & -0.241 & -0.375 & -0.394 & 0.484 & -0.394 \\
\hline $\mathrm{Fe}^{3+}$ & -0.253 & 0.186 & 0.095 & 0.250 & -0.539 & 0.007 & -0.418 & -0.134 & 0.249 & -0.134 \\
\hline $\mathrm{Fe}^{2+/ 3+}$ & 0.376 & -0.315 & 0.147 & -0.335 & 0.032 & -0.256 & -0.090 & -0.315 & 0.320 & -0.221 \\
\hline
\end{tabular}

${ }^{a}$ Correlation is significant at the 0.01 level (2-tailed); ${ }^{\mathrm{b}}$ correlation is significant at the 0.05 level (2-tailed).

The values of significant correlation coefficients are labeled in bold and underlined. 
Table 3 Estimated cell specific ammonia oxidation rates of AOA and AOB, and a comparison with relevant studies

\begin{tabular}{|c|c|c|c|c|}
\hline \multicolumn{2}{|c|}{ Organism and environment } & \multicolumn{2}{|c|}{$\begin{array}{l}\text { Cell specific ammonia oxidation rate } \\
\quad \text { (fmol } \mathrm{NH}_{3} \text { oxidized/(cell-hr)) }\end{array}$} & \multirow[t]{2}{*}{ References } \\
\hline & & $\mathrm{AOB}^{\mathrm{a}}$ & $\mathrm{AOA}^{\mathrm{a}}$ & \\
\hline \multirow[t]{2}{*}{ Pure culture } & $\mathrm{AOB}$ & $0.9-83$ & & Belser, 1979; Ward et al., 1989 \\
\hline & $\mathrm{AOA}$ & & $0.08-0.59$ & Könneke et al., 2005; Treusch et al., 2005 \\
\hline \multirow[t]{2}{*}{ Environment } & Agricultural soil & $0.20-15.6$ & & Okano et al., 2004 \\
\hline & Others, e.g. sludge waste & $0.22-12.4$ & & Wagner et al., 1995 \\
\hline \multirow[t]{2}{*}{ Environment } & Agricultural soil $(0-20 \mathrm{~cm})$ & 0.25 & 0.002 & Jia and Conrad, 2009 \\
\hline & Agricultural soil $(40-50 \mathrm{~cm})$ & 1.78 & 0.005 & \\
\hline A surface & Sediment & 0.57 & 1.25 & This study \\
\hline B surface & Sediment/soil & 0.02 & 9.28 & \\
\hline C surface & Soil & 0.26 & 0.93 & \\
\hline D surface & Soil & 0.91 & 0.35 & \\
\hline E surface & Soil & 10.90 & 0.04 & \\
\hline $\mathrm{D}(0-30 \mathrm{~cm})$ & Soil & $0.91-27.00$ & $0.02-0.04$ & \\
\hline $\mathrm{D}(30-50 \mathrm{~cm})$ & Soil & $160.0-166.6$ & $0.12-0.15$ & \\
\hline $\mathrm{D}(50-80 \mathrm{~cm})$ & Soil & ND & $0.14-0.26$ & \\
\hline
\end{tabular}

a The rate of ammonia oxidized per ammonia-oxidizing bacteria (AOB) or ammonia-oxidizing archaea (AOA) cell was calculated by dividing the potential nitrification rates mentioned before, assuming each cell has equal activity and soil nitrate produced is solely from either AOB or AOA alone, and each genome of $\mathrm{AOB}$ and $\mathrm{AOA}$ contains 2.5 and 1.0 amo A gene copies, respectively.

limiting step was seldom investigated. In this study, we confirmed that the sites near the land/water interface $(0.5-$ $2 \mathrm{~m}$ ) showed higher potential nitrification rates (4.4 and $6.1 \mu \mathrm{g} \mathrm{NO}{ }_{2}^{-}-\mathrm{N} /(\mathrm{g}$ dws.hr) in sites $\mathrm{C}$ and $\mathrm{B}$, respectively compared with 1.0-1.7 $\mu \mathrm{g} \mathrm{NO} \mathrm{NO}^{-}-\mathrm{N} /(\mathrm{g}$ dws $\cdot \mathrm{hr})$ in other sites, Fig. 2) which were within the range of field data in other wetlands (1.0-11.3 $\mu \mathrm{g} \mathrm{NO}_{2}{ }^{-}-\mathrm{N} /(\mathrm{g} \mathrm{dws} \cdot \mathrm{hr})$ ) (Herrmann et al., 2008; Wang et al., 2011). In transition areas, substantial increase of enzyme activity, microbe numbers and oxygen consumption have been observed where the subsurface flow paths and roots encountered each other (McClain et al., 2003). Therefore, the roots of the reed (Phragmites australis var. Baiyangdiansis), which is the dominant hydrophyte in this area, may play a key role in the formation of nitrification hot spots in the littoral buffer zone.

The variety of AOB was found well correlated with the corresponding PNRs. Furthermore, a consistently higher abundance of AOB than AOA was detected in the sites with higher PNRs. All the results strongly suggested that the AOB may functionally dominate nitrification in the littoral buffer zone. It has been reported that AOA predominated among ammonia-oxidizing prokaryotes in soil and marine environments (Leininger et al., 2006; Wuchter et al., 2006). However, it also has been observed that AOB outnumbered AOA in certain environments (Di et al., 2009; Jia and Conrad 2009; Wang et al., 2011). Some environmental factors like $\mathrm{pH}$, salinity, and fertilization have been identified as affecting their distribution (Erguder et al., 2009). However, the key influencing factor is still not well understood and is difficult to assess (Erguder et al., 2009). In this study the ammonia concentration seemed to be one of the most decisive factors as shown in Fig. 2. When the ammonia is limited, the half-saturation constant $K_{\mathrm{S}}$ for $\mathrm{NH}_{3}$ oxidation (133 nmol/L for AOA) provides substantial evidence for the predominance from the biochemical kinetics (MartensHabbena et al., 2009). The $K_{\mathrm{S}}$ for $\mathrm{NH}_{3}$ oxidation of AOB (0.14 and $1.9 \mathrm{mmol} / \mathrm{L})$ in soil for Nitrosospira sp. $\mathrm{AV}$ and Nitrosomonas europaea (Taylor and Bottomley, 2006)) is much higher than that of archaea, therefore the
AOA would outcompete when facing a limited substrate of ammonia. Moreover, a high concentration of ammonia (3.08 $\mathrm{mmol} / \mathrm{L})$ would inhibit the ability of thermophilic ammonia-oxidizing Crenarchaeote to oxidize ammonia (Hatzenpichler et al., 2008). In this case, with polluted lake water as the main source of ammonium $(1.43 \mathrm{mmol} / \mathrm{L})$, a better condition was provided for the growth and competition of AOB in the transition sites. However, higher abundance of AOA was detected in deep samples where the dissolved oxygen (DO) was low and difficult to measure in this study. DO might be among the most determinative parameters for nitrification (Dong et al., 2011) and the distribution of AOA and AOB (Erguder et al., 2009), and AOA were found to tolerate a wide range and low oxygen levels in water (Francis et al., 2005; Könneke et al., 2005). The higher abundance of AOA in deep samples indicates that the AOA may be more important than AOB in some environments with limited oxygen available, which was further implied by the analysis of estimated cell-specific rates (Table 3). The distribution of $\mathrm{AOA}$ and $\mathrm{AOB}$ may be affected by multiple factors including DO (Erguder et al., 2009), pH (Wang et al., 2011), Eh (Höfferle et al., 2010) or nitrogen substrate (Jia and Conrad, 2009). Combining all the results in previous work and this study, it can be concluded that the AOA are more adapted to the low-nutrient, -oxygen, -pH environment.

The richness predicted by Shannon (0.39-2.21 for AOA, 1.23-1.73 for AOB) and Simpson (0.06-0.75 for AOA, $0.12-0.29$ for $\mathrm{AOB}$ ) index were mostly within the ranges of the reported Shannon (0.44-2.12 for AOA, 0.33-2.02 for AOB) and Simpson (0.10-0.84 for AOA, 0.11-0.84 for AOB) index in wetlands (Beman and Francis, 2006; Mosier and Francis 2008; Wang et al., 2011). Higher richness was observed in the surface layer compared with deep layers, which was consistent with a previous study in a wetland (Li et al., 2011). The majority of the archaeal sequences were assigned into two branches without a clear difference between surface and bottom samples, but most of the bacterial sequences in surface samples were closely related to the Nitrosopira sequences, which is in agreement 
with a previous study (Höfferle et al., 2010). However, little difference can be inferred from the phylogeny in the five sites for both $\mathrm{AOA}$ and $\mathrm{AOB}$, suggesting a blending condition of land and water environments in the littoral buffer zone.

\section{Conclusions}

In the present study, potential nitrification rate measurement, amoA-encoding ammonia oxidizers abundance and diversity analyses were carried out along the gradient of a littoral buffer zone. The study area showed high spatial heterogeneity in nitrification rates and abundance of bacterial ammonia oxidizers. The potential nitrification rates were proportional to the amoA gene abundance of bacterial ammonia oxidizers, but had no significant correlation with archaeal ammonia oxidizers. Bacterial versus archaeal amoA gene copy numbers showed bacterial amoA to be numerically dominant in most of the surface samples. However, in deep soils, the archaeal ammonia oxidizers appeared to play a more important role in this littoral buffer zone.

\section{Acknowledgments}

The authors would like to thank Prof. Junxin Liu and Prof. Jizheng He for their kind assistance. This study was supported by the National Natural Science Foundation of China (No. 20877086; 21077119), the National Basic Research Program (973) of China (No. 2009CB421103), and the National Water Project of China (No. 2009ZX07209005; 2008ZX07421-001; 2008ZX07209-006-02). The author Guibing Zhu gratefully acknowledges the support of Beijing Nova Program (No. 2011104) and K. C. Wong Education Foundation, Hong Kong.

\section{References}

Belser L W, 1979. Population ecology of nitrifying bacteria. Annual Review of Microbiology, 33(1): 309-333.

Beman J M, Francis C A, 2006. Diversity of ammonia-oxidizing archaea and bacteria in the sediments of a hypernutrified subtropical estuary: Bahia del Tobari, Mexico. Applied and Environmental Microbiology, 72(12): 7767-7777.

Canfield D E, Thamdrup B, Hansen J W, 1993. The anaerobic degradation of organic matter in Danish coastal sediments: Iron reduction, manganese reduction, and sulfate reduction. Geochimica et Cosmochimica Acta, 57(16): 3867-3883.

Di H J, Cameron K C, Shen J P, Winefield C S, O'Callaghan $\mathrm{M}$, Bowatte $\mathrm{S}$ et al., 2009. Nitrification driven by bacteria and not archaea in nitrogen-rich grassland soils. Nature Geoscience, 2(9): 621-624.

Dong Y M, Zhang Z J, Jin Y W, Li Z R, Lu J, 2011. Nitrification performance of nitrifying bacteria immobilized in waterborne polyurethane at low ammonia nitrogen concentrations. Journal of Environmental Sciences, 23(3): 366-371.

Erguder T H, Boon N, Wittebolle L, Marzorati M, Verstraete W, 2009. Environmental factors shaping the ecological niches of ammonia-oxidizing archaea. FEMS Microbiology Reviews, 33(5): 855-869.
Francis C A, Roberts K J, Beman J M, Santoro A E, Oakley B B, 2005. Ubiquity and diversity of ammonia-oxidizing archaea in water columns and sediments of the ocean. Proceedings of the National Academy of Sciences USA, 102(41): 1468314688.

Groffman P M, Tiedje J M, 1989. Denitrification in north temperate forest soils: relationships between denitrification and environmental factors at the landscape scale. Soil Biology and Biochemistry, 21(5): 621-626.

Hatzenpichler R, Lebedeva E V, Spieck E, Stoecker K, Richter A, Daims $\mathrm{H}$ et al., 2008. A moderately thermophilic ammoniaoxidizing crenarchaeote from a hot spring. Proceedings of the National Academy of Sciences USA, 105(6): 21342139.

Herrmann M, Saunders A M, Schramm A, 2008. Archaea dominate the ammonia-oxidizing community in the rhizosphere of the freshwater macrophyte Littorella uniflora. Applied and Environmental Microbiology, 74(10): 3279-3283.

Höfferle Š, Nicol G W, Pal L, Hacin J, Prosser J I, MandićMulec I, 2010. Ammonium supply rate influences archaeal and bacterial ammonia oxidizers in a wetland soil vertical profile. FEMS Microbiology Ecology, 74(2): 302-315.

Jia Z J, Conrad R, 2009. Bacteria rather than Archaea dominate microbial ammonia oxidation in an agricultural soil. Environmental Microbiology, 11(7): 1658-1671.

Könneke M, Bernhard A E, de la Torre J R, Walker C B, Waterbury J B, Stahl D A, 2005. Isolation of an autotrophic ammonia-oxidizing marine archaeon. Nature, 437(7058): 543-546.

Koops H P, Pommerening-Röser A, 2001. Distribution and ecophysiology of the nitrifying bacteria emphasizing cultured species. FEMS Microbiology Ecology, 37(1): 1-9.

Kurola J, Salkinoja-Salonen M, Aarnio T, Hultman J, Romantschuk M, 2005. Activity, diversity and population size of ammonia-oxidising bacteria in oil-contaminated landfarming soil. FEMS Microbiology Letter, 250(1): 33-38.

Leininger S, Urich T, Schloter M, Schwark L, Qi J, Nicol G W et al., 2006. Archaea predominate among ammonia-oxidizing prokaryotes in soils. Nature, 442(7104): 806-809.

Li M, Cao H L, Hong Y G, Gu J D, 2011. Spatial distribution and abundances of ammonia-oxidizing archaea (AOA) and ammonia-oxidizing bacteria (AOB) in mangrove sediments. Applied Microbiology and Biotechnology, 89(4): 12431254.

Martens-Habbena W, Berube P M, Urakawa H, de La Torre J $\mathrm{R}$, Stahl D A, 2009. Ammonia oxidation kinetics determine niche separation of nitrifying Archaea and Bacteria. Nature, 461(7266): 976-979.

McClain M E, Boyer E W, Dent C L, Gergel S E, Grimm N B, Groffman P M et al., 2003. Biogeochemical hot spots and hot moments at the interface of terrestrial and aquatic ecosystems. Ecosystems, 6(4): 301-312.

Merrill A G, Zak D R, 1992. Factors controlling denitrification rates in upland and swamp forests. Canadian Journal of Forest Research, 22(11): 1597-1604.

Morris J T, 1991. Effects of nitrogen loading on wetland ecosystems with particular reference to atmospheric deposition. Annual Review of Ecology, Evolution, and Systematics, 22(1): 257-279.

Mosier A C, Francis C A, 2008. Relative abundance and diversity of ammonia-oxidizing archaea and bacteria in the San Francisco Bay estuary. Environmental Microbiology, 10(11): 3002-3016.

Okano Y, Hristova K R, Leutenegger C M, Jackson L E, Denison 
R F, Gebreyesus B et al., 2004. Application of real-time PCR to study effects of ammonium on population size of ammonia-oxidizing bacteria in soil. Applied and Environmental Microbiology, 70(2): 1008-1016.

Park H D, Wells G F, Bae H, Criddle C S, Francis C A, 2006. Occurrence of ammonia-oxidizing archaea in wastewater treatment plant bioreactors. Applied and Environmental Microbiology, 72(8): 5643-5647.

Peng Y Z, Zhu G B, 2006. Biological nitrogen removal with nitrification and denitrification via nitrite pathway. Applied Microbiology and Biotechnology, 73(1): 15-26.

Phillips E J P, Lovley D R, 1987. Determination of Fe(III) and $\mathrm{Fe}(\mathrm{II})$ in oxalate extracts of sediment. Soil Science Society of America Journal, 51(4): 938-941.

Rotthauwe J H, Witzel K P, Liesack W, 1997. The ammonia monooxygenase structural gene $a m o \mathrm{~A}$ as a functional marker: molecular fine-scale analysis of natural ammoniaoxidizing populations. Applied and Environmental Microbiology, 63(12): 4704-4712.

Schloss P D, Handelsman J, 2005. Introducing DOTUR, a computer program for defining operational taxonomic units and estimating species richness. Applied and Environmental Microbiology, 71(3): 1501-1506.

Tamura K, Dudley J, Nei M, Kumar S, 2007. MEGA4: molecular evolutionary genetics analysis (MEGA) software version 4.0. Molecular Biology and Evolution, 24(8): 1596-1599.

Taylor A E, Bottomley P J, 2006. Nitrite production by $\mathrm{Ni}$ trosomonas europaea and Nitrosospira sp. AV in soils at different solution concentrations of ammonium. Soil Biology and Biochemistry, 38(4): 828-836.

Tiedje J M, 1988. Ecology of denitrification and dissimilatory nitrate reduction to ammonium. Biology of Anaerobic Microorganisms, 717: 179-244.

Treusch A H, Leininger S, Kletzin A, Schuster S C, Klenk H P, Schleper C, 2005. Novel genes for nitrite reductase and Amo-related proteins indicate a role of uncultivated mesophilic crenarchaeota in nitrogen cycling. Environmental Microbiology, 7(12): 1985-1995.

Van den Heuvel R N, Hefting M M, Tan N C G, Jetten M S M, Verhoeven J T A, 2009. $\mathrm{N}_{2} \mathrm{O}$ emission hotspots at different spatial scales and governing factors for small scale hotspots.
Science of the Total Environment, 407(7): 2325-2332.

Verhoeven J T A, Arheimer B, Yin C Q, Hefting M M, 2006. Regional and global concerns over wetlands and water quality. Trends in Ecology E Evolution, 21(2): 96-103.

Vidon P, Allan C, Burns D, Duval T P, Gurwick N, Inamdar S et al., 2010. Hot spots and hot moments in riparian zones: potential for improved water quality management. Journal of the American Water Resources Association, 46(2): 278298.

Wagner M, Rath G, Amann R, Koops H P, Schleifer K H, 1995. In situ identification of ammonia-oxidizing bacteria. Systematic and Applied Microbiology, 18(2): 251-264.

Wang H J, Wang W D, Yin C Q, Wang Y C, Lu J W, 2006. Littoral zones as the "hotspots" of nitrous oxide $\left(\mathrm{N}_{2} \mathrm{O}\right)$ emission in a hyper-eutrophic lake in China. Atmospheric Environment, 40(28): 5522-5527.

Wang S Y, Wang Y, Feng X J, Zhai L M, Zhu G B, 2011. Quantitative analyses of ammonia-oxidizing Archaea and bacteria in the sediments of four nitrogen-rich wetlands in China. Applied Microbiology and Biotechnology, 90(2): 779-787.

Ward B B, Glover H E, Lipschultz F, 1989. Chemoautotrophic activity and nitrification in the oxygen minimum zone off Peru. Deep Sea Research Part A Oceanographic Research Papers, 36(7): 1031-1051.

Wuchter C, Abbas B, Coolen M J L, Herfort L, Van Bleijswijk J, Timmers $\mathrm{P}$ et al., 2006. Archaeal nitrification in the ocean. Proceedings of the National Academy of Sciences USA, 103(33): 12317-12322.

Zhu G B, Jetten M S M, Kuschk P, Ettwig K F, Yin C Q, 2010. Potential roles of anaerobic ammonium and methane oxidation in the nitrogen cycle of wetland ecosystems. Applied Microbiology and Biotechnology, 86(4): 10431055.

Zhu G B, Peng Y Z, Li B K, Guo J H, Yang Q, Wang S Y, 2008. Biological removal of nitrogen from wastewater. Reviews of Environmental Contamination E Toxicology, 192: 159-195.

Zhu G B, Wang S Y, Wang Y, Wang C X, Risgaard-Petersen N, Jetten M S M et al., 2011. Anaerobic ammonia oxidation in a fertilized paddy soil. The ISME Journal, 5(12): 19051912. 